\title{
Effects of Surface Wetness Periods on Development of Soybean Rust Under Field Conditions
}

\author{
Dario F. Narváez, Postdoctoral Research Associate, University of Florida-North Florida Research and Education \\ Center (NFREC), Quincy 32351; Wayne M. Jurick II, Postdoctoral Research Associate, University of Florida, \\ Gainesville 32611; and James J. Marois, Professor of Plant Pathology, and David L. Wright, Professor of Agron- \\ omy, University of Florida-NFREC
}

\begin{abstract}
Narváez, D. F., Jurick, W. M., II, Marois, J. J., and Wright, D. L. 2010. Effects of surface wetness periods on development of soybean rust under field conditions. Plant Dis. 94:258-264.

Soybean rust (SBR), caused by Phakopsora pachyrhizi, has the potential to be an economic threat to U.S. soybean production after its arrival to the continental United States in 2004. The use of fungicides to control SBR may be problematic due to the large acreage that needs to be protected, the high costs of fungicides, and the cost of application. Cultural practices such as the use of reduced seed rates, increased row widths, and row orientation to the sun have been prescribed as environmental modifications that create a microclimate less conducive to foliar disease development. Therefore, our objective was to determine the influence of different periods of leaf wetness and respective microenvironments on infection and rust development on soybean plants in the field. A misting irrigation system was developed and applied on MGV soybean for 1 min every $30 \mathrm{~min}$ for $0-, 6-, 12-$, and 18 -h periods. This study indicates that extended periods of leaf wetness $(18 \mathrm{~h})$ increase disease severity and the rate of spread of the disease in the upper canopy. These results, in combination with spore monitoring, may be used to refine models of pathogen reproduction, prediction, and risk in a certain regions.
\end{abstract}

Soybean rust (SBR), caused by Phakopsora pachyrhizi Syd. \& P. Syd., is a potentially devastating disease that has been known since the early 1900s in the Eastern Hemisphere $(6,16,18)$. It is now established in all major soybean-producing countries, posing a serious threat to U.S. soybean industry with estimated yield loses of up to $80 \%$ during optimal conditions for disease development $(3-5,29)$. Severely infected plants have fewer pods and smaller seeds that are of poor quality. The risk of infection is also further corroborated by recent studies demonstrating the ability of the pathogen to survive during winter on kudzu in Florida and Louisiana $(15,27)$.

No commercial soybean cultivars are available in the United States that have been confirmed to be SBR resistant (28), although there are efforts to address the problem by conventional as well as mo-

Corresponding author: D. F. Narváez

E-mail: dario.narvaez@monsanto.com

Current address of D. F. Narváez: Monsanto Company, $800 \mathrm{~N}$ Lindbergh Blvd., Mail Zone U2D, St. Louis 63137.

* The $\boldsymbol{e}$-Xtra logo stands for "electronic extra" and indicates that Figures 1 to 7 appear in color in the online edition.

Accepted for publication 30 October 2009.

doi:10.1094/PDIS-94-2-0258

(C) 2010 The American Phytopathological Society lecular approaches $(13,24,26)$. Current control measures include the use of fungicides in the triazole and strobilurin classes. Complete reliance on fungicides to control SBR is not ideal due to the large acreage needing to be protected, high cost of the fungicide materials and application, and potential development of fungicide resistance by this pathogen. Modified cultural practices may help to reduce the reliance on fungicides or possibly reduce the total number of fungicide applications needed while maintaining acceptable soybean yields.

Since the early 1970 s, research conducted by Melching et al. $(22,23)$ in the Biological Safety Level 3 (BLSL3-P) plant disease containment facility at the United States Department of AgricultureAgricultural Research Service, Frederick, MD has contributed to the understanding of the biology and environmental requirements of SBR $(3,5,6,17,21-23)$ and include information on effects of temperature and moisture on infection of SBR (21-23). A minimum of 6 to $7 \mathrm{~h}$ of continuous leaf wetness (LW) was reported to be required for SBR lesions to develop at favorable dew temperatures ( 18 to $26.5^{\circ} \mathrm{C}$ ) when viable uredospores were present on a susceptible soybean (23). Now that $P$. pachyrhizi has been discovered in the southeastern United States, studies can be conducted outside disease containment facilities. Results from research conducted in the laboratory, greenhouse, and field will provide a better understanding of SBR and its control. We will use the term "surface wetness" for defining the general moisture in a plant canopy. Surface wetness has been used by several authors in the past when discussing $\operatorname{LW}(7,12)$. In this article, moisture on any part of a plant will be defined as surface wetness and includes LW.

The objectives of this study were to (i) determine the effect of different misting periods on the soybean canopy microclimate, (ii) determine the effect of surface wetness duration periods on the spatial distribution and rate of spread (incidence and severity) of an inoculated and a natural SBR epidemic in soybean canopies under field conditions, and (iii) compare the incidence and disease progress between inoculated and natural SBR epidemics under the effect of different surface wetness duration periods in the field.

\section{MATERIALS AND METHODS}

The experiment was repeated three times during two different periods, twice in 2007 and once in 2008. Two distant fields ( 36.6 by $54.9 \mathrm{~m}, 800 \mathrm{~m}$ apart) in 2007 and one field ( 36.6 by $54.9 \mathrm{~m}$ ) in 2008 at the University of Florida, North Florida Research and Education Center, in Quincy, were planted with a determinant soybean cultivar with group maturity V (DP $5915 \mathrm{RR}$ ) on $38-\mathrm{cm}$ row spacing in a randomized complete block design with misting periods as treatments $(0,6,12$, and $18 \mathrm{~h}$ ).

Treatment plots were 6.1 by $6.1 \mathrm{~m}$ and randomized in a triplicate design. Treatments were separated by $6.1 \mathrm{~m}$ and 17 -row borders from each other to minimize any border effect. A programmed misting system was implemented to provide different surface wetness periods. Working misting area within each plot was 4.6 by $4.6 \mathrm{~m}$. Experiments in 2007 and 2008 were planted, inoculated (two inoculated fields: one in 2007 and one in 2008), and evaluated at the same time to facilitate comparisons.

The misting system used a micromist nozzle (Plastro Tornado Mister; Bowsmith Inc., Exeter, CA) placed $38 \mathrm{~cm}$ high in the canopy on a 0.7-by-0.7-m grid throughout the plot. Each mister delivered approximately 125 to $150 \mathrm{ml}$ per $30 \mathrm{~s}$. The timer used to program the different misting peri- 
ods was the SoloRain 8014 DuraLife (LR Nelson Corporation, Peoria, IL). This misting system was set to spray for $30 \mathrm{~s}$ every $30 \mathrm{~min}$ for 6,12 , and $18 \mathrm{~h}$. The misting periods started at $\mathrm{V} 7 \mathrm{in}$ all fields and $24 \mathrm{~h}$ prior to the field inoculations. The misting periods were set to begin as follows: $0-\mathrm{h}$ treatment $=$ no misting applied; 6 -h treatment $=$ on at 00:00 (midnight), off at 06:00; 12-h treatment $=$ on at 21:00, off at 09:00; and 18-h treatment $=$ on at 18:00, off at 12:00 (noon).
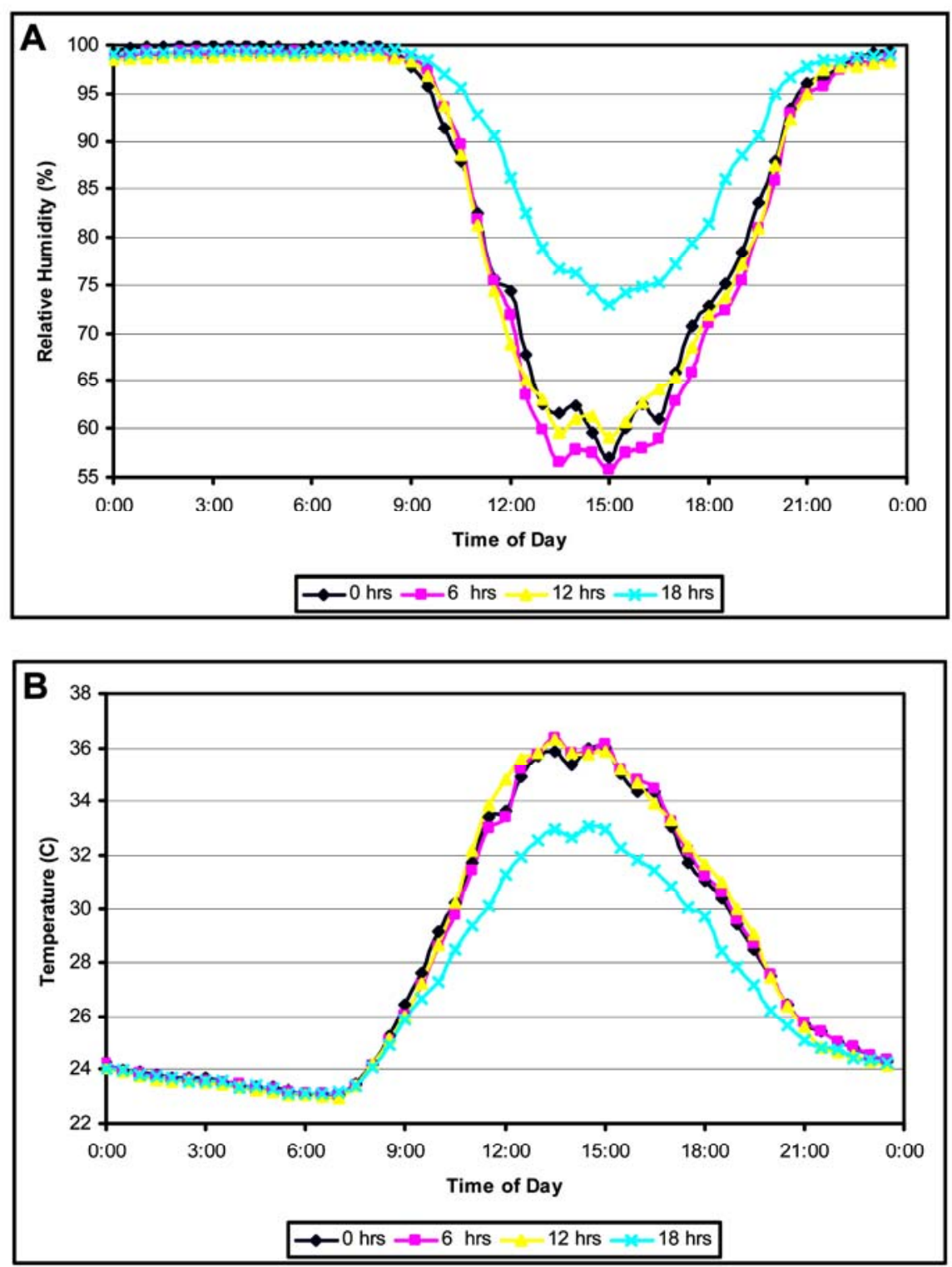

Fig. 1. Effect of the misting periods (h) on the canopy $\mathbf{A}$, relative humidity and $\mathbf{B}$, temperature. Note that the effects of the different misting periods continued for several hours after the actual misting was stopped. Treatments were $0 \mathrm{~h}=$ no misting, $6 \mathrm{~h}=$ misting from 12:00 to 06:00, $12 \mathrm{~h}=$ misting from 21:00 to $09: 00,18 \mathrm{~h}=$ misting from 18:00 to $12: 00$.

Standard irrigation was applied to the whole field dependent on environmental requirements until the crop reached V7 growth stage and prior to inoculation. Misting irrigation was not applied before inoculation to ensure uniform plant growth.

Microenvironment measurements. Microenvironmental changes within the soybean canopy were monitored $38 \mathrm{~cm}$ above the ground (mid-canopy level) in the center of each plot with Log Tag microloggers (MicroDAQ.com, Ltd. Contoocook, NH). The microloggers were programmed to record air temperature $(\mathrm{T})$ and relative humidity (RH) every 22 min during the entire growing and misting season. Vapor pressure deficit (VPD) and dew point temperatures $\left(T_{d}\right)$ were calculated from the air temperature and $\mathrm{RH}$ using the following equation:

$$
\begin{gathered}
\mathrm{VPD}=\left[6.108 \times e^{(17.27 \times T / T-237.3)}\right] \\
{[1-\mathrm{RH} / 100] / 10 \mathrm{kPa}(31,32)}
\end{gathered}
$$

Unlike RH, VPD has a simple, nearly straight-line relationship to the rate of evapotranspiration and other measures of evaporation. These were correlated with the changes in the microclimate as conducive factors for the enhancement of the SBR disease development. The dew point temperature is $T_{d}=[b \times \alpha(T, R H)] /[a-\alpha(T$, $R H)](2)$, where $\alpha(T, R H)=[(a \times T) /(b+T)]$ $+\ln (R H)$, and where $T$ is the temperature $\left({ }^{\circ} \mathrm{C}\right), R H$ is the measured $\mathrm{RH}, T_{d}$ is the calculated dew point temperature $\left({ }^{\circ} \mathrm{C}\right)$, and $\mathrm{ln}$ refers to the natural logarithm. The constants are $a=17.27$ and $b=237.7\left({ }^{\circ} \mathrm{C}\right)$.

The uncertainty in the measured dew point temperature is a function of the measured temperature and $\mathrm{RH}$ and the uncertainties associated with those measurements. The uncertainty in the calculated dew point temperature is $\pm 0.4^{\circ} \mathrm{C}$.

This expression is based on the "Magnus" (or "Magnus-Tetens") approximation for the saturation vapor pressure of water in air as a function of temperature.(2) It is considered valid for $0^{\circ} \mathrm{C}<T<60^{\circ} \mathrm{C}, 1 \%<$ $R H<100 \%, 0^{\circ} \mathrm{C}<T_{d}<50^{\circ} \mathrm{C}$.

Spore suspension density and spore germination. $P$. pachyrhizi uredospores were collected from leaves of soybean plants that had been mist inoculated (14) with a Florida isolate of $P$. pachyrhizi and grown in the greenhouse under optimal

\begin{tabular}{|c|c|c|c|c|c|c|c|c|c|c|}
\hline \multirow[b]{3}{*}{ Misting periods $(h)^{z}$} & \multirow{2}{*}{\multicolumn{2}{|c|}{ RH (\%) }} & \multirow{2}{*}{\multicolumn{2}{|c|}{$\mathbf{T}\left({ }^{\circ} \mathbf{C}\right)$}} & \multirow{2}{*}{\multicolumn{2}{|c|}{ VPD $\left({ }^{\circ} \mathrm{C}\right)$}} & \multicolumn{4}{|c|}{ Frequency of days $(\%)^{y}$} \\
\hline & & & & & & & \multicolumn{2}{|c|}{$\mathrm{T}=20-25^{\circ} \mathrm{C}$} & \multicolumn{2}{|c|}{$\mathrm{RH}>85 \%$} \\
\hline & Mean & SD & Mean & SD & Mean & SD & Mean & SD & Mean & SD \\
\hline 0 & 86.83 & 1.30 & 28.13 & 0.15 & 0.80 & 0.09 & 10.16 & 0.13 & 16.84 & 0.43 \\
\hline 6 & 85.45 & 2.51 & 28.18 & 0.21 & 0.88 & 0.17 & 10.25 & 0.30 & 16.40 & 0.69 \\
\hline 12 & 86.27 & 2.27 & 28.13 & 0.32 & 0.81 & 0.12 & 10.59 & 0.06 & 16.32 & 0.97 \\
\hline 18 & 92.01 & 2.02 & 26.14 & 0.20 & 0.41 & 0.09 & 11.01 & 0.15 & 19.16 & 1.07 \\
\hline
\end{tabular}

Table 1. Effect of surface misting periods on microclimate variables within soybean canopies ${ }^{\mathrm{x}}$

${ }^{\mathrm{x}}$ Values are means \pm standard deviation (SD) of individual sensors in three replicate blocks and averaged per treatment across the studied years. $\mathrm{T}=$ canopy air temperature, $\mathrm{RH}=$ canopy relative humidity, $\mathrm{VPD}=$ vapor pressure deficit.

${ }^{y}$ Data for number of hours per day with the indicated $\mathrm{T}$ and $\mathrm{RH}$.

${ }^{\mathrm{z}}$ Misting times periods were 00:00 to 06:00 for 6-h treatment, 21:00 to 09:00 for 12-h treatment, and 18:00 to 12:00 for 18-h treatment. 
SBR conditions just prior to inoculation. The rust uredospores were collected by vacuum from the leaves into $20-\mathrm{ml}$ glass vials with a large cyclone spore collector (G-R Manufacturing Co., Manhattan, KS).

Approximately $0.5 \mathrm{ml}$ of uredospores were suspended in $100 \mathrm{ml}$ of doubledeionized water $\left(\mathrm{ddH}_{2} \mathrm{O}\right)$. Small spore dilutions were made to calculate spore suspension. Estimates of spore suspension density were made by counting spores on 9- $\mathrm{ml}^{2}$ grids of the Bright-Line Hematocymeter (Hausser Scientific, Horsham, PA). Uredospores present in $0.1-\mu \mathrm{l}$ subsamples of the factor diluted spore suspension were counted in triplicate 100 times to estimate the number of spores per milliliter. The mean estimated value was later used to adjust the spore suspension to have a concentration of 130,000 spores $/ \mathrm{ml}$.

A 1,000- $\mu$ l subsample of the spore suspension was placed on $1.25 \%$ water agar in triplicate 5-cm-diameter culture plates. Plates were incubated at room temperature for $12 \mathrm{~h}$. A minimum of 200 spores/plate was examined to determine germination percentages. A spore was considered germinated if the length of the germ tube equaled or exceeded the minor diameter of the spore. Magnifications of $\times 100$ or higher with a calibrated ocular micrometer was used to measure the germ tube length.
Disease induction, assessment, and evaluation. Soybean plants were inoculated at one of the fields in 2007 (2007-1) and 2008 when the fourth trifoliate soybean leaves were fully expanded (V7 growth stage; 9) and a day after the misting irrigation started. The SBR inoculum suspension was applied with an atomizer on both sides of leaflets of a soybean plant located at the center of each one of the treatment plots. Only leaflets of the lower canopy level were inoculated. On average, there were approximately $3.28 \mathrm{ml}$ of inoculum suspension per leaflet. The second soybean field in 2007 (2007-2) was left to natural SBR infection to evaluate any possible differences in disease development.

Effect of surface wetness duration periods on the spatial distribution and rate of spread (incidence and severity) of SBR. Disease assessments started the same day in all the experiments. Assessments were made weekly at 10 specific points (consisting of one plant for each point) around the inoculated plant (focus plant) within each treatment plot. At each particular point, 10 trifoliate leaves were evaluated from the lower, middle, and upper canopy. Assessment of disease incidence and severity were determined by visual weekly observations once the disease was first detected at the foci plant, and until lower leaves dropped or mid- and upper-canopy leaves showed high levels of disease severity. Incidence was recorded as the fraction of leaflets out of 10 with disease symptoms. Disease severity assessments were recorded as a percentage of leaf covered by lesions using a 0 -to- $100 \%$ scale. All disease assessments were done by the same person using prepared figures as guides. All experiments for the area under the disease progress curve (AUDPC) was calculated by the formula (34):

$$
\text { AUDPC }=\sum_{i=1}^{n}\left[\left(x_{i+1}+x_{i}\right) / 2\right]\left(t_{i+1}-t_{i}\right)
$$

Data analyses. Data were analyzed by analysis of variance (ANOVA) (PROC GLM) and means were separated by Tukey's Studentized Range (highly significant difference) in SAS (SAS Institute Inc., Cary, NC) with repeated measures and block as the random effect. A mixed linear model ANOVA was used to determine effects of $\mathrm{T}, \mathrm{RH}$, and $\mathrm{LW}$ on incidence and severity (20). $F$ tests were used to determine if main effects of their interactions significantly affected the disease progress. Degree of freedom for the $F$ tests was calculated using the Satterthwaite method (20). Means were separated and main effects used Fisher's least significant difference; the level of significance for all comparison was $5 \%$. In the mixed linear model ANOVA, T, RH, and LW periods
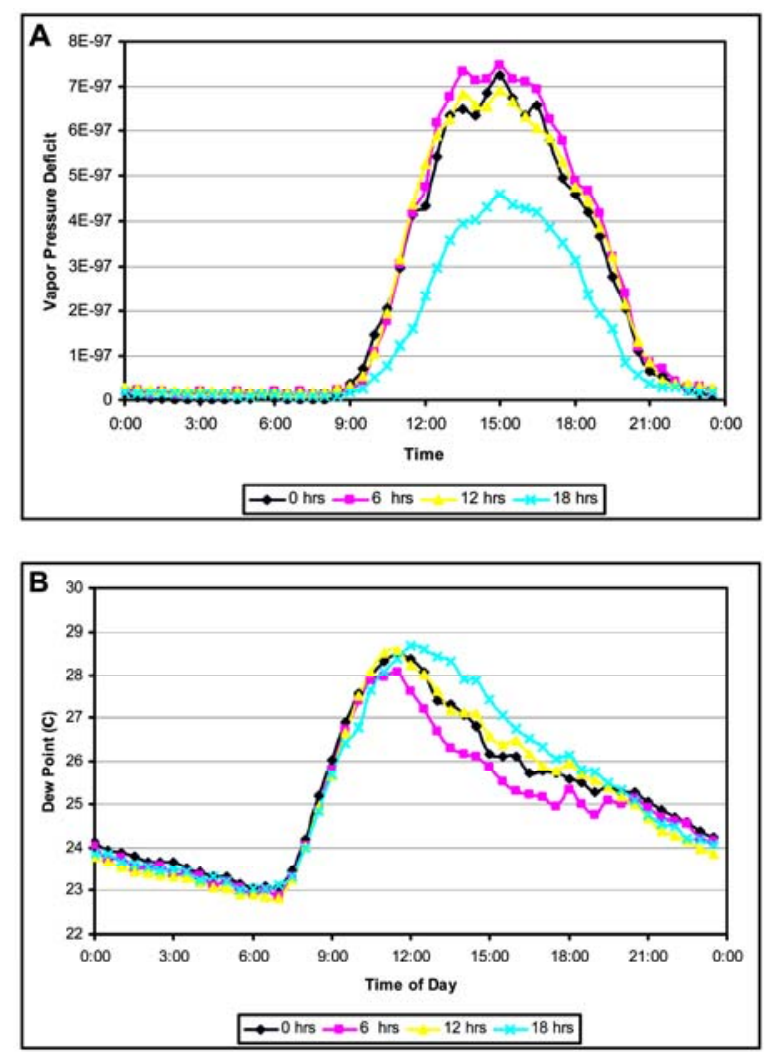

Fig. 2. Effect of the misting periods (h) on the canopy A, vapor pressure deficit and $\mathbf{B}$, dew point. Note that the effects of the different misting periods continued for several hours after the actual misting was stopped. Treatments were $0 \mathrm{~h}=$ no misting, $6 \mathrm{~h}=$ misting from 12:00 to $06: 00,12 \mathrm{~h}$ $=$ misting from 21:00 to $09: 00,18 \mathrm{~h}=$ misting from 18:00 to 12:00.
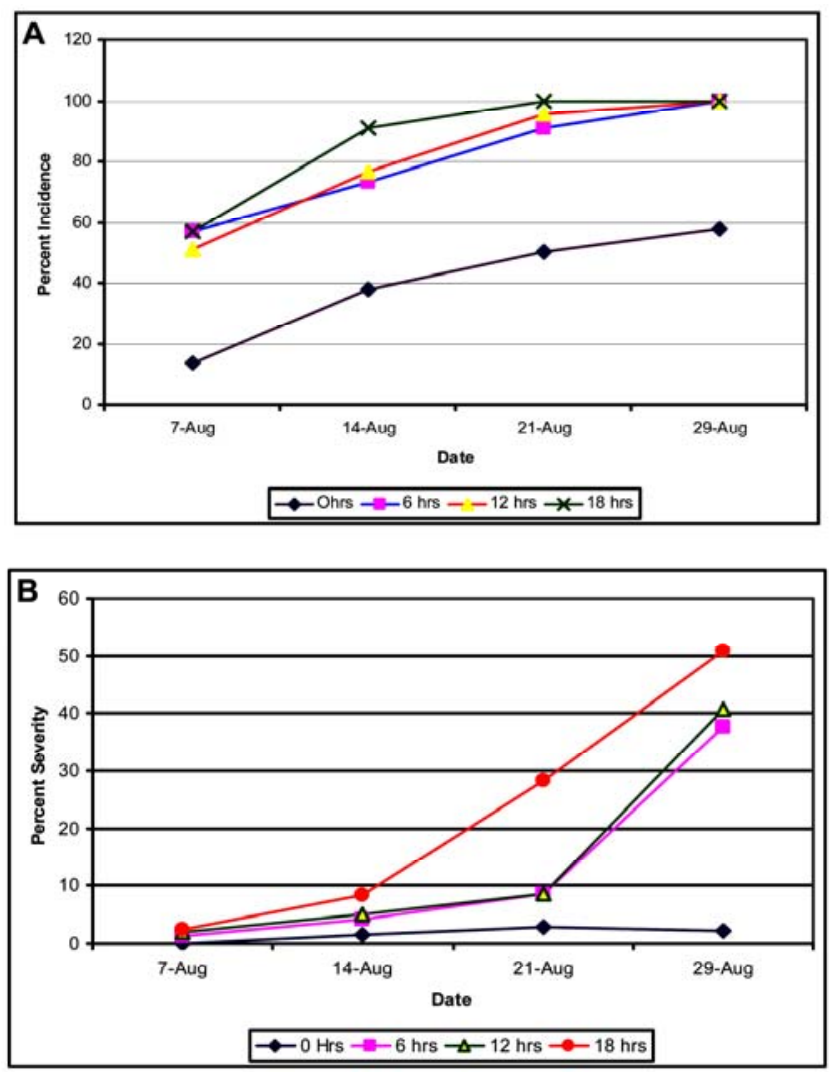

Fig. 3. Effect of misting periods on the $\mathbf{A}$, incidence and $\mathbf{B}$, severity of the naturally occurring soybean rust epidemic (2007-2). Treatments were $0 \mathrm{~h}$ $=$ no misting, $6 \mathrm{~h}=$ misting from 12:00 to 06:00, $12 \mathrm{~h}=$ misting from 21:00 to $09: 00,18 \mathrm{~h}=$ misting from 18:00 to $12: 00$. 
(and their interactions) were considered as class (category) variables.

\section{RESULTS}

Effect of misting periods on microclimate variables. The 18 -h surface wetness period was the only treatment that had a significant effect on the soybean canopy microclimate, especially when misting occurred between 0900 and 2100 . RH was the microenvironmental variable most dramatically affected by $18 \mathrm{~h}$ of surface wetness treatment. The average maximum $\mathrm{RH}$ during this period was significantly higher $(15.8 \%)$ than the control treatment (Fig. 1A; Table 1). T and VPD were also affected by $18 \mathrm{~h}$ of LW. The average maximum $\mathrm{T}$ and maximum $\mathrm{VPD}$ were $2.4^{\circ} \mathrm{C}$ and $2.69 \mathrm{E}-97 \mathrm{kPa}$ lower than the control treatment, respectively (Figs. 1B, 2A, and 3; Table 1). Temperatures for dew formation increased as the duration of surface wetness period increased. The 18-h treatment had significantly higher levels of disease severity for both inoculated and natural infection (Fig. 2B). The 6- and 12$\mathrm{h}$ treatments were not significant from the control treatment (Figs. 1 and 2).

Spatial and temporal spread of an inoculated SBR epidemic versus a natural epidemic. The onset time of SBR was different for the natural (2007-2) versus the inoculated field (2007-1). The SBR development started first in the field with the inoculated epidemic. The disease developed on the naturally infected field at $\mathrm{R} 1,11$ days after the symptoms were visible on the inoculated field. Disease developed uniformly in numerous locations in the naturally inoculated field; however, the initial incidence of SBR under the surfacemisting treatments was significantly higher on the naturally occurring epidemic than the inoculated epidemic (Figs. 3 and 4). These results were expected because the inoculum source in the inoculated epidemic came from a single focus in contrast to possible multiple infection sources in the natural infection. The incidence was significantly lower in the control treatment (no misting irrigation) than in the naturally occurring epidemic. The misting treatments favored the incidence of disease in both the natural and inoculated epidemic; however, in both cases, the 18-h misting period treatment had a higher effect on the incidence on SBR (Figs. 3A and 4A). The differences between the disease progress of SBR in the inoculated study and natural infection were not significant (Table 2). The SBR disease severity pattern and the effect of the surface wetness periods were similar for both the inoculated and natural epidemic (Figs. 3B and 4B). The 18-h treatment had a significantly higher effect on the disease severity on both the inoculated and the natural occurring epidemic (Figs. 3 and 4). There were significant differences in the incidence and severity among the misting periods. The 18-h treatment had the most effect on the incidence and severity of disease development in the field (Table 2).

Effect of temperature during dew period on SBR disease development. Experiments were designed to quantify the effects of microenvironmental variables in
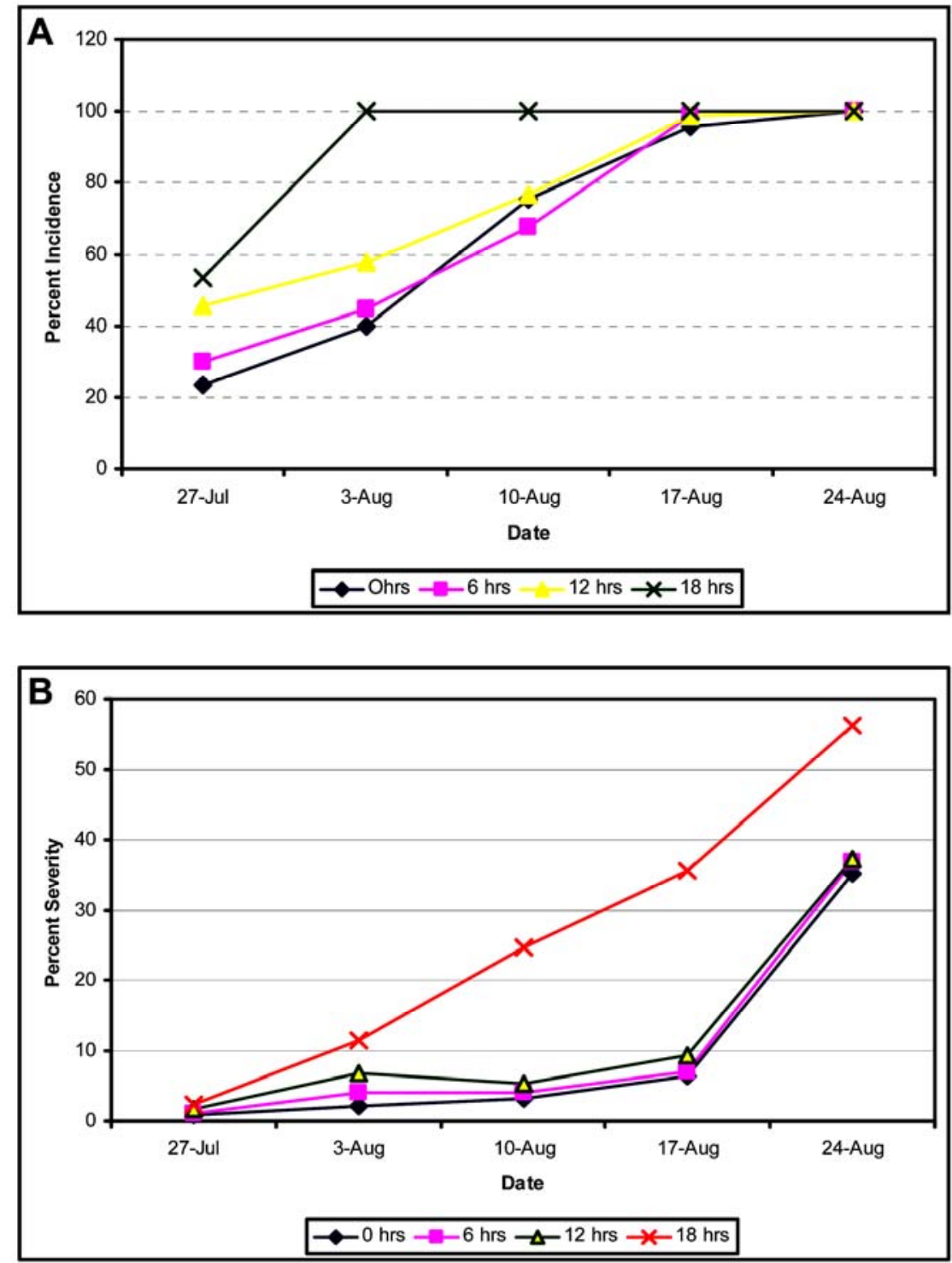

Fig. 4. Effect of overall surface misting periods on the $\mathbf{A}$, incidence and $\mathbf{B}$, severity of an inoculated soybean rust epidemic (2007-1). Treatments were $0 \mathrm{~h}=$ no misting, $6 \mathrm{~h}=$ misting from 12:00 to 06:00, $12 \mathrm{~h}=$ misting from 21:00 to 09:00, $18 \mathrm{~h}=$ misting from 18:00 to 12:00.

Table 2. Effect of misting periods on soybean rust (SBR) in Florida ${ }^{\mathrm{w}}$

\begin{tabular}{llllllll}
\hline & \multicolumn{3}{c}{ Disease incidence $^{\mathbf{x}}$} & & \multicolumn{3}{c}{ Disease severity $^{\mathbf{y}}$} \\
\cline { 2 - 4 } \cline { 7 - 8 } Misting $(\mathbf{h})^{\mathbf{z}}$ & $\mathbf{2 0 0 7 - 1}$ & $\mathbf{2 0 0 7 - 2}$ & $\mathbf{2 0 0 8}$ & & $\mathbf{2 0 0 7 - 1}$ & $\mathbf{2 0 0 7 - 2}$ & $\mathbf{2 0 0 8}$ \\
\hline 0 & $59.1 \mathrm{c}$ & $33.0 \mathrm{c}$ & $63.8 \mathrm{~b}$ & & $9.5 \mathrm{~b}$ & $1.67 \mathrm{c}$ & $20.5 \mathrm{c}$ \\
6 & $69.1 \mathrm{bc}$ & $70.3 \mathrm{~b}$ & $65.5 \mathrm{~b}$ & & $10.6 \mathrm{~b}$ & $12.9 \mathrm{~b}$ & $22.2 \mathrm{~b}$ \\
12 & $75.6 \mathrm{~b}$ & $75.8 \mathrm{~b}$ & $70.6 \mathrm{ab}$ & & $12.0 \mathrm{~b}$ & $14.0 \mathrm{ab}$ & $23.9 \mathrm{~b}$ \\
18 & $87.6 \mathrm{a}$ & $87.8 \mathrm{a}$ & $79.0 \mathrm{a}$ & & $26.0 \mathrm{a}$ & $22.5 \mathrm{a}$ & $29.1 \mathrm{a}$ \\
\hline
\end{tabular}

${ }^{\text {w}}$ Disease was inoculated in 2007-1 and 2008 fields and 2007-2 field was naturally infected by SBR Means not followed by a common letter within each column are significantly different $(P \leq 0.05)$ according to Fisher's least significant difference test $t$ test.

${ }^{\mathrm{x}}$ Incidence was recorded as the fraction of leaflets out of 10 plants with SBR signs or symptoms.

${ }^{y}$ Disease severity assessments were recorded as a percentage of leaf covered by lesions using a 0-to$100 \%$ scale. Assessment of the disease incidence and severity was determined by visual weekly observations once the disease was detected at the foci plant (approximately 14 days after germination) and until lower leaves were severely diseased and dropped.

${ }^{\mathrm{z}}$ Misting times periods were 00:00 to 06:00 for 6-h treatment, 21:00 to 09:00 for 12-h treatment, and 18:00 to $12: 00$ for 18 -h treatment. 


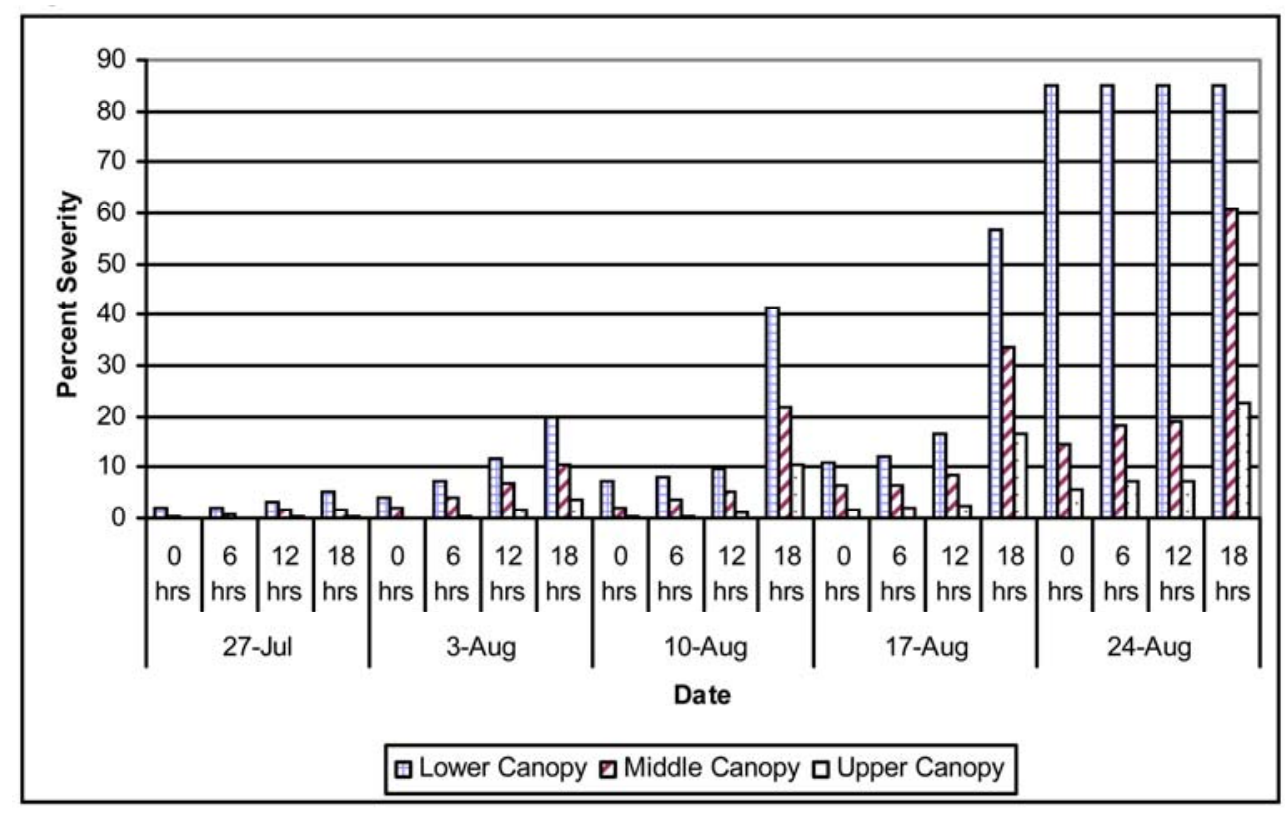

Fig. 5. Effect of surface misting periods on the establishment and progression of an inoculated soybean rust epidemic in the field (2007-1 and 2008) at different canopy levels. Treatments were $0 \mathrm{~h}=$ no misting, $6 \mathrm{~h}=$ misting from 12:00 to 06:00, $12 \mathrm{~h}=$ misting from 21:00 to 09:00, $18 \mathrm{~h}=$ misting from 18:00 to 12:00.
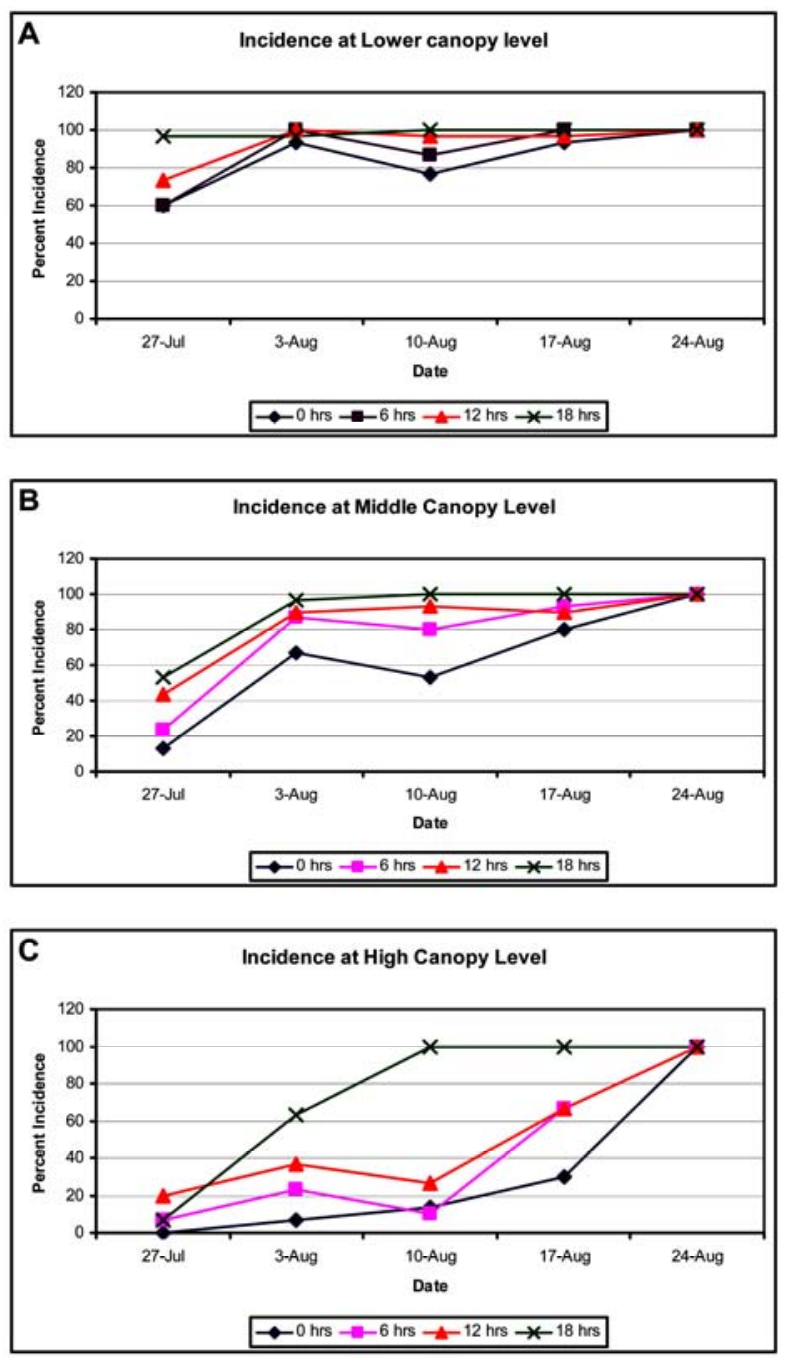

Fig. 6. Comparison of the soybean rust incidence among the three soybean canopy levels as a response to the misting treatments. Incidence at A, lower; $\mathbf{B}$, middle; and $\mathbf{C}$, high canopy level. Treatments were $0 \mathrm{~h}=$ no misting, $6 \mathrm{~h}=$ misting from 12:00 to $06: 00,12 \mathrm{~h}=$ misting from 21:00 to 09:00, $18 \mathrm{~h}=$ misting from 18:00 to 12:00.
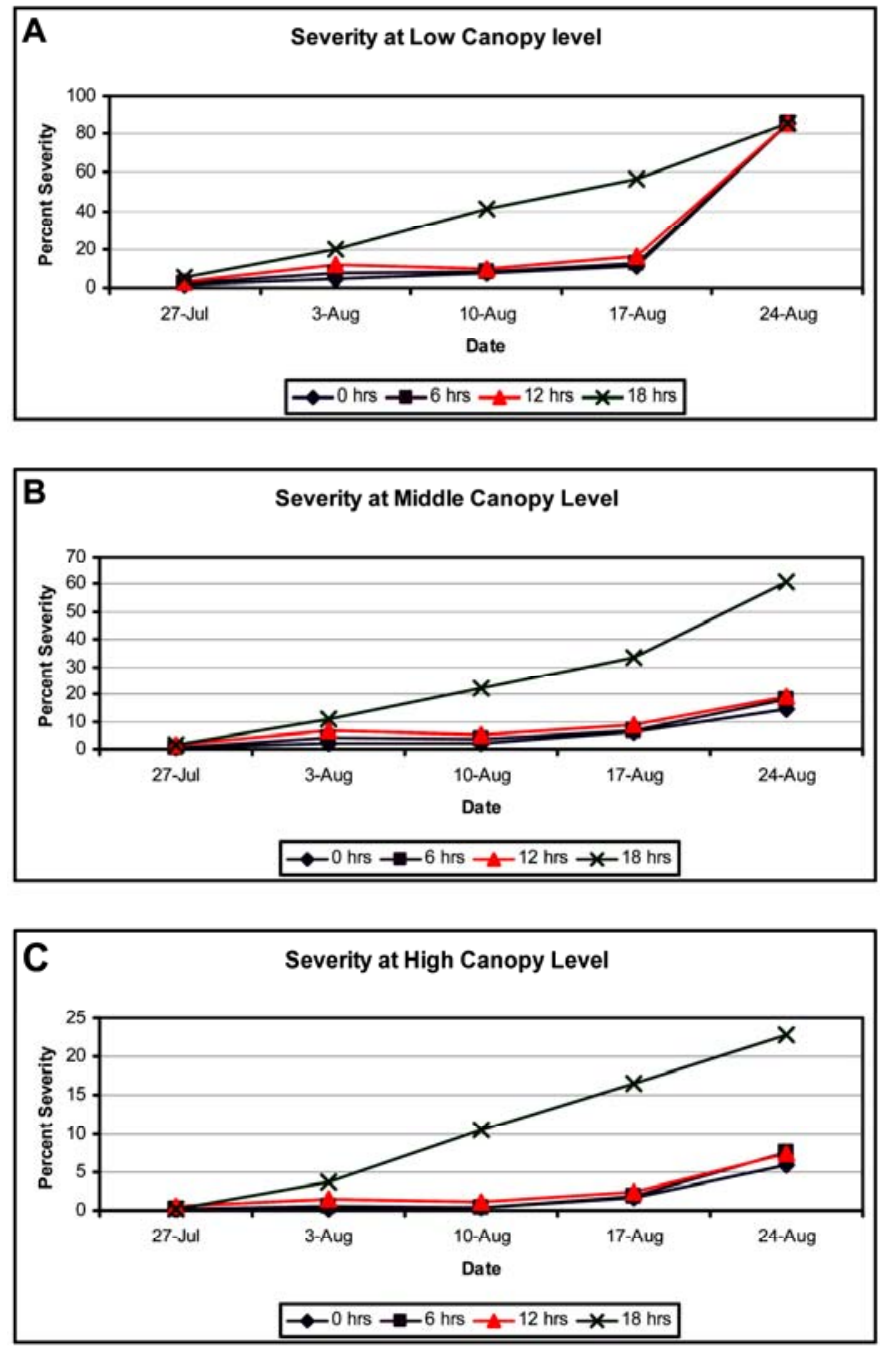

Fig. 7. Comparison of the soybean rust severity among the three soybean canopy levels as a response to the misting treatments. Severity at $\mathbf{A}$, lower; $\mathbf{B}$, middle; and $\mathbf{C}$, high canopy level. Treatments were $0 \mathrm{~h}=$ no misting, $6 \mathrm{~h}=$ misting from 12:00 to $06: 00,12 \mathrm{~h}=$ misting from 21:00 to $09: 00,18 \mathrm{~h}=$ misting from 18:00 to 12:00. 
response to the duration of surface wetness on infection of $P$. pachyrhizi. After inoculation, no minimum period of surface wetness was necessary for SBR infection (Fig. 4). The disease efficacy was more responsive to the 18-h treatment and its influence on $\mathrm{RH}$ than $\mathrm{T}$ during the incubation period. $\mathrm{A}$ minimum dew period of 12-h immediately after inoculation significantly increased disease but did not alter the relative response to RH in any subsequent period. (Figs. 1A and 4). The vertical spread of SBR throughout the canopies had similar patterns among the misting treatments (Fig. 5). The percent incidence and severity was higher on the lower canopy, decreased at mid-canopy, and was much less on the upper canopy (Figs. 6 and 7). The percent incidence and severity at each canopy level increased as the length of misting periods increased, with the 18-h treatment having the most significant effect on incidence of SBR (Figs. 6 and 7; Table 3). The 18-h misting period was also the only treatment that had a significant effect on the percent severity and the AUDPC at each canopy level. There were no significant differences on severity or the AUDPC among the 0-, 6-, and 12-h misting periods at any of the canopy levels (Tables 4 and 5).

\section{DISCUSSION}

Water on the leaves of many crop plants plays an important role in the development of foliar diseases. Although rain and irrigation contribute to disease development, the majority of wetting events results from cooling of leaves below the dew point temperature of surrounding air. Thus, most models of crop foliar diseases include factors related to both pathogen biology and environmental regulation of the presence of water on leaves (1).
Most foliar fungal plant pathogens require specific leaf surface conditions for their spores to germinate; favorable temperature, and a film of water on the plant surface (or a high RH). These conditions must last long enough for the pathogen to penetrate the plant; otherwise, the germinated spore dry out and die (1). The presence of dew on the leaf surface and extending this natural period of LW result in increased fungal growth (30) and the presence of foliar diseases (19).

With fungal diseases, moisture on the foliage determines the production of spores and their survival. The results here are consistent with what has been shown for other fungal pathogens. Gross et al. (11) reported the severity of brown patch (Rhizoctonia solani) increases as the length of LW increases above $9 \mathrm{~h}$. The longer the leaf surface is wet, the greater the risk of infection and the greater the number of infections per leaf. Fidanza et al. (10) reported that minimal infection of this disease occurs when the duration of LW is below $6 \mathrm{~h}$, with severe infections occurring when the length of LW increases from 8 to $10 \mathrm{~h}$. Irrigation in the afternoon is directly associated with an increase in infection, especially when warm day temperatures are followed by cool night temperatures (8). Once the optimum temperature is reached, gray leaf spot of perennial ryegrass and tall fescue (Festuca arundinacea Schreb) caused by Pyricularia grisea (Cooke) Sacc. increases in severity with the length of $\operatorname{LW}(25,32,33,35)$.

The requirement of LW for these processes explains, in part, why conditions that maintain prolonged dew formation and other microenvironmental factors result in the rapid development of SBR. A relatively wet soil can apparently extend the duration of LW by $2 \mathrm{~h}$ compared with a drier soil. Cloudy atmospheric or shaded conditions, dry areas, and low-speed air movements could extend moist periods of time where the leaves do not dry out, facilitating spores of some fungal organisms to germinate and produce a motile spore that must swim in a film of water before infection can occur.

Throughout the major soybeanproducing areas of the United States, dew conditions may permit rust initiation and

Table 5. Effect of surface misting periods on severity of soybean rust as measured by the area under the disease progress curve (AUDPC) at each soybean canopy level ${ }^{\mathrm{y}}$

\begin{tabular}{lccc}
\hline & \multicolumn{3}{c}{ AUDPC } \\
\cline { 2 - 4 } Misting periods $(\mathbf{h})^{\mathbf{z}}$ & Low & Medium & High \\
\hline 0 & $247 \mathrm{a}$ & $437 \mathrm{a}$ & $87 \mathrm{a}$ \\
6 & $347 \mathrm{a}$ & $724 \mathrm{a}$ & $108 \mathrm{a}$ \\
12 & $409 \mathrm{a}$ & $761 \mathrm{a}$ & $134 \mathrm{a}$ \\
18 & $695 \mathrm{~b}$ & $1,161 \mathrm{~b}$ & $293 \mathrm{~b}$ \\
$P$ value & 0.0046 & 0.0009 & 0.0018 \\
\hline
\end{tabular}

${ }^{y}$ Means not followed by a common letter within each column are significantly different $(P<0.05)$ according to Fisher's least significant difference test $t$ test.

${ }^{\mathrm{z}}$ Misting times periods were 00:00 to 06:00 for 6-h treatment, 21:00 to 09:00 for 12-h treatment, and 18:00 to 12:00 for 18-h treatment.

Table 3. Effect of misting periods on soybean rust (SBR) at each canopy level ${ }^{\mathrm{x}}$

\begin{tabular}{|c|c|c|c|c|c|c|}
\hline \multirow[b]{2}{*}{ Canopy level } & \multicolumn{3}{|c|}{ Disease incidence ${ }^{y}$} & \multicolumn{3}{|c|}{ Disease severity $^{\mathrm{z}}$} \\
\hline & 2007-1 & $2007-2$ & 2008 & $2007-1$ & $2007-2$ & 2008 \\
\hline Low & $91.5 \mathrm{a}$ & $83.9 \mathrm{a}$ & 83.6 & $27.9 \mathrm{a}$ & $24.5 \mathrm{a}$ & $36.7 \mathrm{a}$ \\
\hline Middle & $78.2 \mathrm{~b}$ & $73.5 \mathrm{~b}$ & 74.3 & $11.4 \mathrm{~b}$ & $10.9 \mathrm{~b}$ & $24.0 \mathrm{~b}$ \\
\hline Upper & $48.8 \mathrm{c}$ & $42.7 \mathrm{c}$ & 51.4 & $4.2 \mathrm{c}$ & $3.0 \mathrm{c}$ & $11.0 \mathrm{c}$ \\
\hline
\end{tabular}

${ }^{x}$ Disease was inoculated in 2007-1 and 2008 fields and 2007-2 field was naturally infected by SBR. Means not followed by a common letter within each column are significantly different $(P \leq 0.05)$ according to Fisher's least significant difference test $t$ test.

${ }^{y}$ Incidence was recorded as the fraction of leaflets out of 10 plants with SBR signs or symptoms.

${ }^{\mathrm{z}}$ Disease severity assessments were recorded as a percentage of leaf covered by lesions using a 0-to-100\% scale. Assessment of the disease incidence and severity were determined by visual weekly observations once the disease was detected at the foci plant (approximately 14 days after germination), and until lower leaves severely diseased dropped or mid- and upper-canopy leaves showed high levels of disease severity.

Table 4. Effect of surface misting periods on the incidence and severity of soybean rust at each soybean canopy level (averaged across dates) ${ }^{\mathrm{y}}$

\begin{tabular}{|c|c|c|c|c|c|c|}
\hline \multirow[b]{2}{*}{ Misting period $(h)^{z}$} & \multicolumn{3}{|c|}{ Incidence per canopy level (\%) } & \multicolumn{3}{|c|}{ Severity per canopy level (\%) } \\
\hline & Low & Medium & High & Low & Medium & High \\
\hline 0 & $85 \mathrm{a}$ & $63 \mathrm{a}$ & $30 \mathrm{a}$ & $22 \mathrm{a}$ & $5 \mathrm{a}$ & $2 \mathrm{a}$ \\
\hline 6 & $89 a b$ & $77 \mathrm{ab}$ & $41 \mathrm{ab}$ & $23 \mathrm{a}$ & $7 \mathrm{a}$ & $2 \mathrm{a}$ \\
\hline 12 & $93 \mathrm{ab}$ & $83 \mathrm{ab}$ & $50 \mathrm{ab}$ & $25 \mathrm{a}$ & $8 \mathrm{a}$ & $3 \mathrm{a}$ \\
\hline 18 & $99 \mathrm{~b}$ & $90 \mathrm{~b}$ & $74 \mathrm{~b}$ & $42 \mathrm{a}$ & $26 \mathrm{~b}$ & $11 \mathrm{~b}$ \\
\hline$P$ value & 0.0609 & 0.0624 & 0.0244 & 0.2988 & $<0.0001$ & $<0.0001$ \\
\hline
\end{tabular}

${ }^{\mathrm{y}}$ Means not followed by a common letter within each column are significantly different $(P<0.05)$ according to Fisher's least significant difference test $t$ test.

${ }^{\mathrm{z}}$ Misting times periods were 00:00 to 06:00 for 6-h treatment, 21:00 to 09:00 for 12-h treatment, and 18:00 to 12:00 for 18-h treatment. 
spread if viable uredospores are present on the crop. Twelve or more hours of moist foliage can trigger a major disease outbreak. Practices should be followed that limit LW to less than 12 consecutive hours. The risk of infection is corroborated by results from this study and previous studies $(15,16,18,21-23,27)$. The length of time, T, and $\mathrm{RH}$ that are optimum for the development of SBR would occur in most of the U.S. soybean-producing regions as well as where kudzu is predominant.

This is the first report concerning the effects of excess surface moisture on SBR disease development in the field in North America. Data from this study have shown that extended periods of surface wetness $(18 \mathrm{~h})$ not only increase disease severity but also increase the rate of spread of the disease to the upper canopy. Information from this study may be used to refine models of pathogen reproduction and disease forecasting to better predict SBR disease development in the field.

\section{ACKNOWLEDGMENTS}

Funding and support was made possible by the North Central Soybean Research Program and the University of Florida, IFAS, North Florida Research and Education Center (NFREC). We thank D. Mailhot, N. Dufault, G. Kelly O'Brien, and all the staff at the NFREC for their help with these experiments.

\section{LITERATURE CITED}

1. Agrios, G. N. 1988. Plant Pathology, 3rd ed. Academic Press, Inc.

2. Barenbrug, A. W. T. 1974. Psychrometry and Psychrometric Charts, 3rd ed. Cape and Transvaal Printers Ltd., Cape Town, S.A.

3. Bonde, M. R., Melching, J. S., and Bromfield, K. R. 1976. Histology of the susceptible pathogen relationship between Glycine max and Phakopsora pachyrhizi, the cause of soybean rust. Phytopathology 66:1290-1294.

4. Bromfield, K. R. 1980. Soybean rust: Some considerations relevant to threat analysis. Prot. Ecol. 2:251-257.

5. Bromfield, K. R. 1984. Soybean Rust. Monograph No. 11. The American Phytopathological Society, St. Paul, MN.

6. Bromfield, K. R., Meching, J. S., and Kingsolver, C. H. 1980. Virulence and aggressiveness of Phakopsora pachyrhizi isolates causing soybean rust. Phytopathology 70:17-21.

7. Deshpande, R. Y., Hubbard, K. G., Coyne, D. P., Steadman, J. R., and Parkhurst, A. M. 1995. Estimating leaf wetness in dry bean canopies as prerequisite to evaluating white mold dis- ease. Agron. J. 87:613-619.

8. Dickson, L. S. 1930. The effect of air temperature on the pathogenicity of Rhizoctonia solani parasitizing grasses on putting-green turf. Phytopathology 20:597-608.

9. Fehr, W. R., and Caviness, C. E. 1977. Stages of soybean development. In: Special Report 80,36, Cooperative Extension Services, Iowa State University, Ames.

10. Fidanza, M. A., Dernoeden, P. H., and Grybauskas, A. P. 1966. Development and field validation of a brown patch warning model for perennial ryegrass turf. Phytopathology 86:385-390.

11. Gross, M. K., Latin, R., and Satini, J. B. 1998. The influence of temperature and leaf wetness duration on infection of perennial ryegrass by Rhizoctonia solani. Plant Dis. 82:531-534.

12. Huber, L, and Gillespie, T. J. 1992. Modeling leaf wetness in relation to plant disease epidemiology. Annu. Rev. Phytopathol. 30:533577.

13. Hyten, D. L, Hartman, G. L., Nelson, R. L., Frederick, R. D., Concibido, V. C., Narvel, J. M., and Cregan, P. B. 2007. Map location of the Rpp1 locus that confers resistance to soybean rust in soybean. Crop Sci. 47:837-840.

14. Isard, S. A., Dufault, N. S., Miles, M. R., Hartman, G. L., Russo, J. M., De Wolf, E. D., and Morel, W. 2006. The effect of solar irradiance on the mortality of Phakopsora pachyrhizi urediniospores. Plant Dis. 90:941-945.

15. Jurick, W. M., II, Narváez D. F., Brennan, M. M., Harmon, C. L., Marois, J. J., Wright, D. L., and Harmon, P. F. 2008. Winter survival of the soybean rust pathogen, Phakopsora pachyrhizi, in Florida. Plant Dis. 92:1551-1558.

16. Keogh, R. C. 1974. Studies on Phakopsora pachyrhizi Syd.: the causal agent of soybean rust. M.S. thesis, University of Sydney, Australia.

17. Kingsolver, C. H., Melching, J. S., and Bromfield, K. R. 1983. The threat of exotic plant pathogens to agriculture in the United States. Plant Dis. 67:595-600.

18. Kitani, K., and Inoue, Y. 1960. Studies of the soybean rust and its control measure. Part 1. Studies of the soybean rust. Bull. Shikoku Agric. Exp. Stn. 5:319-342. (In Japanese with English summary.)

19. Leslie, A. R., ed. 1994. Handbook of Integrated Pest Management for Turf and Ornamentals. Lewis Publishers.

20. Littell, R. C., Milliken, G. A., Stroup, W. W., and Wolfinger, R. D. 1996. SAS System for Mixed Models. SAS Institute, Inc, Cary, NC.

21. Marchetti, M. A., Meching, J. S., and Bromfield, K. R. 1976. The effects of temperature and dew period on germination and infection by urediospores of Phakopsora pachyrhizi. Phytopathology 66:461-463.

22. Melching, J. S., Bromfield, K. R., and Kingsolver, C. H. 1979. Infection, colonization, and uredospore production on Wayne soybean by four cultures of Phakopsora pachyrhizi, the cause of soybean rust. Phytopathology 69:1262-1265.

23. Melching, J. S., Dowler, W. M., Koogle, D. L., and Royer, M. H. 1989. Effects of duration, frequency, and temperature of leaf wetness periods on soybean rust. Plant Dis. 73:117-112.

24. Monteros, M. J., Missaoui, A. M., Phillips, D. V., Walker, D. R., and Boerman, H. R. 2007. Mapping and confirmation of the 'Hyuuga' red-brown lesion resistance gene for Asian soybean rust. Crop Sci. 47:829-836.

25. Moss, M. A, and Trevathan, L. E. 1987 Environmental conditions conductive to infection of ryegrass by Pyricularia grisea. Phytopathology 77:863-866.

26. Panthee, R. D., Marois, J., Wright, D. L., Narváez, D. F., Yuan, J. S., and Stewart, C. N. Jr. 2008. Differential expression of genes in soybean in response to the causal agent of Asian soybean rust (Phakopsora pachyrhizi Sydow) is soybean growth stage-specific. Theor. Appl. Genet. 118:359-370.

27. Park, S., Chen, Z.-Y., Chanda, A. K., Schneider, R. W., and Hollier, C. A. 2008. Viability of Phakopsora pachyrhizi urediniospores under simulated southern Louisiana winter temperature conditions. Phytopathology 92:1456-1462.

28. Schneider, K. T., DeMortel, M. V., Nettleton, D., Frederick, R. D., Baum T. J., and Whitham, S. A. 2006. Microarray analysis of Rpp3mediated resistance to soybean infection. In: National Rust Symposium. American Phytopathological Society, St. Paul, MN

29. Schneider, R. W., Hollier, C. A., Whitan, H K., Palm, M. E., McKemy, J. M., Hernandez, J. R., Levis, L., and DeVries-Paterson, R. 2005. First report of soybean rust caused by Phakopsora pachyrhizi in the continental United States. Plant Dis. 89:774.

30. Smiley, R. W. 1993. Compendium of Turfgrass Disease, Second Edition. American Phytopathological Society Press, St. Paul, MN.

31. Snyder, R. L., and Shaw. 1984. Converting humidity expressions with computers and calculators. Leaflet 21372, Coop. Ext. Div. Agric. Nat. Resour., University of California.

32. Snyder, R. L., and Paw, U. K. T. 2002. Measuring vapor pressure deficit in the field. Regents of the University of California. http://biomet. ucdavis.edu/biomet/VPD/vpd.htm.

33. Uddin, W., Burpee, L. L., and Stevenson, K. L. 1997. Influence of temperature and leaf wetness duration on development of gray leaf spot (blast) of tall fescue. Agron. Abstr. 137:138.

34. Vidhyasekaran, P. 2004. Concise Encyclopedia of Plant Pathology. Food Products Press and The Haworth Reference Press, Binghamton, NY.

35. Williams, D. W., Powell, A. J., Jr., Dougherty, C. T., and Vincelli, P. 1998. Separation and quantification of the sources of dew on creeping bentgrass. Crop Sci. 28:1613-1617. 